\title{
Regulación de las pensiones alimenticias en Nicaragua
}

\author{
German Antonio Orozco Gadea* \\ Universidad Centroamericana, Nicaragua \\ coordinacioncivil@ns.uca.edu.ni
}

Fecha de recibido: 19 de mayo de 2015/ Fecha de aprobación: 6 de agosto de 2015

\section{Resumen}

El pasado 8 de abril del corriente año entró en vigencia en Nicaragua la Ley $N^{\circ} 870$, mejor conocida como Código de familia. Esta norma aborda las prestaciones alimenticias en el Libro Cuarto. Asistencia familiar y tutela. Título I. Los alimentos, arts. 306 y ss. Mediante esta investigación queremos armonizar la Teoría general de las obligaciones alimenticias con la nueva legislación; también pretendemos exponer algunos de sus aspectos novedosos; comentar los tópicos controversiales que puedan surgir en la aplicación de esta ley; también presentamos los aportes que la jurisprudencia nacional y extranjera han hecho sobre el tema; finalizamos haciendo una tabla comparativa en la que se refleja los aspectos más relevantes entre la anterior legislación y la actual. La rama del Derecho de familia en Nicaragua no ha despertado una esmerada atención entre los investigadores; con este modesto trabajo hacemos nuestra contribución para abrir un pertinente debate que debe acompañar a toda nueva legislación y tratar de motivar a otros investigadores para adentrase en los fértiles campos del Derecho de familia.

\section{Palabras claves}

Pensión / alimentos / familia / cónyuge / menores de edad

*El autor es Profesor asociado de la Universidad Centroamericana, UCA de Nicaragua. 
On 8th April this year, in Nicaragua started of being in force The Law $\mathrm{N}^{\circ} 870$, best known like Code of family. This Law contemplates the Alimony in the fourth book. Family assistance and tutelage. First Title. The alimentation, articles 306 and following. Through this research, we want to harmonize the General theory of alimentary obligations with the new legislation; besides we try to expose some of its novel matters and comment the controversial items that could come out in the application of this law; as well show the contributions that the national and foreign jurisprudence has done about this theme. Finally we finished making a comparison chart between the antique and new law to stand out the relevant matters. The family law in Nicaragua has not attracted careful attention among the researches; with this modest work we contribute to open a relevant debate that must accompany any new legislation and try to motivate other researchers to break through into the fertile fields of family law.

Pension / Alimony / family / Spouse / Minor

\section{Tabla de contenido}

I. Introducción. 2. Regulación constitucional. 3. Antecedentes legislativos y régimen legal vigente. 4. Las obligaciones alimenticias. 4.I. Origen etimológico y evolución histórica. 4.2. Su fundamento. 4.3. Naturaleza jurídica de la deuda alimenticia. 4.4. Características. 4.4. I. Es un derecho recíproco. 4.4.2. Es un derecho personalísimo. 4.4.3. Es un derecho no compensable y es un crédito prioritario. 4.4.4. Es un derecho intransferible. 4.4.5. Es un derecho imprescriptible. 4.4.6. Es un derecho irrenunciable, inembargable e intransigible. 4.4.7. Tiene un carácter proporcional. 4.4.8. Tiene un carácter variable y actualizable. 4.4.9. Es una obligación de tracto sucesivo. 4.4.10. Es una obligación divisible. 4.5. Los sujetos: alimentante (s) y alimentario (s). 4.5.I. Obligados conforme al Derecho de familia. 4.6. Contenido. 4.7. Cuantía y criterios de valoración de la prestación alimenticia. 4.8. Generalidades de la pensión de alimentos. 4.9. Vías legales para exigir el cumplimiento de la pensión alimenticia. 4.10. Incumplimiento de la prestación alimenticia. 4.II. Extinción y cesación de la obligación alimenticia. 5. Conclusiones. Lista de referencias bibliográficas. Abreviaturas. Anexos.

\section{Introducción}

De todas las criaturas que habitan el planeta, el ser humano es uno de los que viene al mundo más desvalido y que permanece mayor tiempo sin bastarse a sí mismo pasa subsistir; en efecto, un infante desde que nace necesita alimento, techo, abrigo, atención médica y un sin número de necesidades sin las cuales no podría subsistir; consecuentemente, requiere una manutención prolongada hasta que se forje su formación integral como hombre o mujer; de igual manera, los adultos mayores y ciertos parientes, pueden constituirse como acreedores de suministros alimenticios, bajo ciertas circunstancias como vejez, enfermedad, invalidez, etc. (MONTERO DUHALT, 1984, p. 60). Aunado a lo anterior, debemos considerar que de acuerdo a nuestra realidad un $44 \%$ de las familias se encuentran dentro de la clasificación de monoparental, principalmente configuradas por madres solteras. En la mayoría de los casos, la parte paterna no 
asume la responsabilidad de forma voluntaria; en consecuencia, es necesario recurrir a la vía judicial. "Según datos de encuesta realizada en diciembre de $200 \mathrm{I}$ siete de cada diez hombres no ayudan a los hijos que no llevan su apellido, en el caso de los hijos reconocidos, 8 de cada 10 padres garantizan la manutención” (MEZA GUTIÉRREZ, 2004, p. 217).

Con ambas citas pretendemos poner de relieve no solo el carácter vital de los alimentos para la subsistencia de los integrantes de la familia; sino también, la áspera realidad que enfrentan en nuestro medio nacional grupos vulnerables como las madres solteras, obligadas a sortear una serie de vicisitudes para llevar el sustento de sus hijos; ciertamente, el fundamento de la prestación alimenticia se encuentra en el principio de la solidaridad familiar (DíEZ PICAZO \& GULLÓN, 2002, p. 47); sin embargo, nuestra Constitución Política establece en el art. 70 una protección a la familia en una doble vertiente: desde la sociedad y el Estado'. En este sentido, el legislador nicaragüense, con el sano propósito de brindar una cobertura jurídica adecuada a todos estos sectores vulnerables (madres solteras, niños, otros parientes en situación de desamparo), ha aprobado una legislación moderna contenida en el Código de familia que representa, el primer esfuerzo codificador en el sentido de aglutinar en un mismo cuerpo de leyes la legislación que antes se encontraba distante y dispersa incluyendo, claro está, las normas que regulan el objeto de estudio de este artículo: las pensiones alimenticias ${ }^{2}$.

La aplicación de una nueva ley, especialmente de un Código, siempre conlleva aparejada dudas e incertidumbres; sin pretender adentrarnos en las parcelas procesales con la espaciosidad que el tema requiere, pretendemos emitir nuestra opinión en aspectos esenciales de las prestaciones alimenticias como la potestad de las autoridades judiciales en el cálculo del monto de las prestaciones de esta índole; procedencia de la demanda de modificación o reforma de la pensión de alimentos; dificultades prácticas en la aplicación de las normas procesales que regulan estos procesos de alimentos; de igual manera analizamos aspectos polémicos como el controversial límite de 21 años para recibir pensiones alimenticias por parte de los hijos e hijas que estén realizando estudios; el criterio de la correspectividad para la fijación de las pensiones alimenticias; el plazo de los 260 días de concepción para poder demandar alimentos para los nasciturus contenido en el art. $319 \mathrm{CF}$.

Así mismo, queremos exponer las líneas doctrinales y jurisprudenciales que surcan nuestro espectro jurídico con el ánimo de aportar nuestro grano de arena y abrir el sano debate que debe preceder en toda manifestación normativa.

\footnotetext{
${ }^{1}$ Art. 70 Cn: "La familia es el núcleo fundamental de la sociedad y tiene derecho a la protección de ésta y del Estado. La persona, la familia y la comunidad son elementos protagónicos del plan de desarrollo humano de la nación". El art. 7 de la Ley 287, Código de la niñez y la adolescencia, publicada en La Gaceta Diario Oficial No 97 del 27 de mayo de 1998, en adelante Ley 287/1998, va más allá y establece la obligación de la familia, la comunidad, la escuela, el Estado y la Sociedad, el cumplimiento de los derechos y garantías de los niños, niñas y adolescentes, entre ellos, por supuesto, están señalados el de los alimentos.

${ }^{2}$ Entre las normativa dispersa en materia de familia derogada por el Código de familia destacamos: Decreto $\mathrm{N}^{\circ}$. 415, "Ley Orgánica del Patrimonio Familiar y de las Asignaciones Forzosas Testamentarias", publicado en La Gaceta, Diario Oficial $\mathrm{N}^{\circ} .86$ del 21 de abril de 1959; Decreto $\mathrm{N}^{\circ} .862$, Ley de adopción, publicado en La Gaceta, Diario Oficial $\mathrm{N}^{\circ}$. 259 del 14 de noviembre de 1981 y su reforma: Ley $\mathrm{N}^{\circ}$. 614, Ley de reforma y adición al Decreto $\mathrm{N}^{\circ}$. 862, Ley de adopción, publicada en La Gaceta, Diario Oficial No. 77 del 25 de abril de 2007; Decreto №. 1065 Ley reguladora de las relaciones madre-padre-hijos, publicada en La Gaceta, Diario Oficial No ${ }^{\circ} 155$ del 3 de julio de 1982; Ley No. 38, Ley para la disolución del matrimonio por voluntad de una de las partes, publicada en La Gaceta, Diario Oficial N ${ }^{\circ}$. 80 del 29 de abril de 1988 y sus reformas: Ley $\mathrm{N}^{\circ}$. 348, Ley de reforma y adiciones al artículo 3 de la Ley $\mathrm{N}^{\circ}$. 38, Ley para la disolución del matrimonio por voluntad de una de las partes, publicada en La Gaceta, Diario Oficial No. 121 del 27 de junio de 2000, Ley $\mathrm{N}^{\circ}$. 485, Ley de adición a los artículos 3 y 8 de la Ley para la disolución del matrimonio por voluntad de una de las partes, publicada en La Gaceta, Diario Oficial No. 98 del 20 de mayo de 2004; Ley No. 143, Ley de alimentos, publicada en La Gaceta, Diario Oficial No $\mathrm{N}^{\circ} 57$ del 24 de marzo de 1992 y sus reformas: Ley $\mathrm{N}^{\circ}$. 482, Ley de reforma al artículo 19 de la Ley $\mathrm{N}^{\circ}$. 143, Ley de Alimentos, publicada en La Gaceta, Diario Oficial No ${ }^{\circ} 97$ del 19 de mayo de 2004; Ley $\mathrm{N}^{\circ}$. 623, Ley de responsabilidad paterna y materna, publicada en La Gaceta, Diario Oficial $\mathrm{N}^{\circ} .120$ del 26 de junio del 2007, Decreto No. 102-2007, Reglamento de la Ley No. 623, Ley de responsabilidad paterna y materna, publicada en La Gaceta, Diario Oficial No. 223 del 20 de noviembre del 2007
} 
Finalizamos este trabajo de investigación con tabla comparativa en la que pretendemos evidenciar los principales cambios establecidos por el Código de familia con respecto a la antigua normativa que regía la materia alimenticia: la Ley 143/1992, Ley de alimentos.

\section{Regulación constitucional}

La Constitución Política nicaragüense, base angular de nuestro ordenamiento jurídico, hace una primera aproximación a la materia alimenticia en el art. 63 que reza así: "Es derecho de los nicaragüenses estar protegidos contra el hambre. El Estado promoverá programas que aseguren una adecuada disponibilidad de alimentos y una distribución equitativa de los mismos". Empero, la impronta que pretendemos atribuir a este trabajo, se sustrae de los derechos sociales, vistos como obligación del Estado de atender a sus habitantes y más bien se adentra en las parcelas del fértil campo del Derecho de familia; así, el legislador constitucional destina el Capítulo IV a regular esta importante rama del derecho; con todo, resulta curioso que en nuestra máxima Norma Jurídica, dentro de este capítulo, no se haga una directa alusión a las obligaciones alimenticias, sino que de forma tangencial aborde las prestaciones alimenticias en el párrafo segundo del art. $73 \mathrm{Cn}$ :

Los padres deben atender el mantenimiento del hogar y la formación integral de los hijos mediante el esfuerzo común, con iguales derechos y responsabilidades. Los hijos, a su vez, están obligados a respetar y ayudar a sus padres. Estos deberes y derechos se cumplirán de acuerdo con la legislación de la materia.

De este precepto debemos deducir que frases como el "mantenimiento del hogar" o "ayudar a sus padres", hacen referencia a lo que la profesora MEZA GuTIÉRREZ (1999, p. 98) denomina "Cargas del hogar", es decir, de forma indirecta aluden a la materia objeto de nuestro estudio: las pensiones de alimentos.

\section{Antecedentes legislativos y régimen legal vigente}

Antes de la entrada en vigencia del Código de familia, la materia alimenticia estaba regulada por la Ley I43, Ley de alimentos, publicada en La Gaceta, Diario Oficial N 57 del 24 de marzo de 1992, en adelante Ley 143//992. Esta norma vino a derogar los arts. 283 a 297 de nuestro Código civil.

Tal disposición normativa, sin duda representa un importante avance dentro de nuestro ordenamiento jurídico, el sentido que vino a revestir de un sustento legal más avanzado del que regía los asuntos alimenticios en el Código civil; empero, la norma referida, como cualquier otra, era perfectible y adolecía de una regulación consistente en ciertas materias como, por ejemplo, alimentos para familiares en la línea colateral; no establece prestaciones de esta índole para los nasciturus; ausencia de pensiones compensatorias; no establece límite de edad para otorgar alimentos a hijos mayores de edad que estaban aprovechando los estudios; no se estipula la prueba del ácido desoxirribonucleico (ADN) para la determinación de la paternidad o maternidad; tampoco se establecía con claridad quién es el juez competente en razón del territorio. En este sentido expresa el magistrado Solís ROMERO (s.f.), como toda ley, imperfecta, representa "al menos un buen esfuerzo para obtener pago de alimentos de quien los necesite" (p. 109).

En la actualidad el Derecho de alimentos está sancionado por la Ley 870, mejor conocida como Código de familia, publicada en La Gaceta, Diario Oficial No 190 del 8 de octubre de 20I4, en adelante Ley 870/20I4. 


\section{Las obligaciones alimenticias}

Esta materia, de capital importancia dentro de las relaciones familiares, es regulada en nuestra legislación por el Código de familia principalmente en el Libro Cuarto. Asistencia familiar y tutela. Título I. Los alimentos, arts. 306 y ss. Como hemos visto, esta ordenación es un reflejo del mandato constitucional del art. $73 \mathrm{Cn}^{3}$.

Con respecto a sus orígenes, "Se afirma que la historia de los alimentos comienza con la historia de la humanidad" (DE IBARROLA, 1978, p. 88, citado por CHÁVEZ ASENCIO, 2007, p. 465); en efecto, el bien más preciado que tiene una persona es la vida y para la subsistencia de la misma, la alimentación tiene un carácter imprescindible.

Su razón de ser no se deriva de consideraciones de orden ético, moral o piadoso, como alimentar al necesitado, socorrer al desvalido o vestir al desnudo, sino que proviene del principio de solidaridad familiar, que obliga a los parientes a suplir las necesidades vitales que cualquier de ellos tenga o no puede autosatisfacer (DíEZ PICAZO \& GULLón, 2002, p. 47); por este motivo, en el art. 315 del Código de familia se lee:

Deberes y derechos en materia de alimentos. El deber de dar alimentos y el derecho de recibirlos se funda en la familia. En la alimentación de la familia deberán contribuir todos los miembros mayores hábiles, unos en dinero y otros con trabajo del hogar, acorde a sus capacidades y posibilidades

\section{I. Origen etimológico y evolución histórica}

El sustantivo alimentos proviene del latín alimentum, que a su vez proviene del verbo alěre (alimentar) y significa el conjunto de cosas que el hombre y los animales comen o beben para subsistir. Cada una de las sustancias que un ser vivo toma o recibe para su nutrición" (CHÁVEZ ASENCIO, 2007, p. 466).

Esta clase de obligaciones fue desconocida en el lus civile romano, pues era inconcebible que al pater familia cargara con tal deber cuando en realidad podía vender o matar a su esposa e hijos.

La primera manifestación de este tipo de prestación aparece en las relaciones de patronato y clientela ${ }^{4}$, y solo tardíamente se inserta en las relaciones familiares dentro de la patria potestas en tiempo de ANTONIO PíO y de MARCO AURELIO para casos singulares y luego se generaliza con el cristianismo basada en la caritas sanguinis. Luego, el Derecho de Justiniano la admite recíprocamente y con independencia de la patria potestad, entre ascendientes y descendientes, entre cónyuges y entre padres e hijos naturales. Podía establecerse también por contrato y legado (Lacruz Berdejo, J. L.; Sacncho Rebudilla, F. de A.; luna Serrano, A., Delgado EcheVerría, F., Rivero HERNÁNDEZ, F., y RAMS AlbeSA, J., 2005, p. 19).

\subsection{Su fundamento}

Las teorías que tratan fundamentar el tema de los alimentos se pueden agrupar en dos tendencias: a) el interés por la vida de quien tiene la necesidad y el derecho a los alimentos (art. 73 Cn precitado); b) el interés de superior de la sociedad y el Estado por la vida de sus ciudadanos (Cfr. art. $63 \mathrm{Cn}$ antes citado); la primera tesis, cimienta esta clase de obligaciones en las relaciones que se derivan del matrimonio, la filiación y parentesco; en cambio, la

\footnotetext{
${ }^{3}$ Art. 73Cn: "Las relaciones familiares descansan en el respeto, solidaridad e igualdad absoluta de derechos y responsabilidades entre el hombre y la mujer.

Los padres deben atender el mantenimiento del hogar y la formación integral de los hijos mediante el esfuerzo común, con iguales derechos y responsabilidades. Los hijos, a su vez, están obligados a respetar y ayudar a sus padres. Estos deberes y derechos se cumplirán de acuerdo con la legislación de la materia".

${ }^{4}$ La clientela consistía en un pacto de sumisión de persona a persona de tal modo que el cliente a cambio de fidelidad y determinados servicios (de carácter agrario, militar, etc.), recibe del patrono protección, sustento y vestidos.
} 
segunda se enfoca hacia cierto officium publicum referido al deber del Estado de garantizar, en la medida de lo posible, que cada uno de los ciudadanos esté proveído de los medios indispensables para la satisfacción de las necesidades de su existencia (LACRUZ BERDEJO et al., 2005, p. 19).

\subsection{Naturaleza jurídica de la deuda alimenticia}

Dentro de esta institución se configura el fenómeno típico que existe en todo obligación: por una parte, un deudor sobre el que pesa el deber de satisfacer una prestación; $y$, por otra, el derecho de un acreedor para exigir el cumplimiento de tal prestación.

Para determinar su naturaleza jurídica, debemos estar conscientes que en esta categoría especial de obligaciones convergen elementos de carácter patrimonial, ético y social que repercuten sobre aspectos sensibles como la defensa de la vida y el desarrollo de la personalidad del alimentario y la convierten en una obligación sui generis; esto explica que pese a ser una obligación económica, pues se traduce en la entrega de cierta cantidad de dinero para cubrir las necesidades básicas, tenga características singulares como ser irrenunciable, imprescriptible, intransferible, inembargable y no compensables (arts. 307 y art. 314 Ley $870 / 2014$ ) 5 .

De acuerdo a los juristas BOSSERT y ZANNONI (2008), el derecho y la correlativa obligación de prestar alimentos se “... deriva de una relación alimentaria legal, de contenido patrimonial, pero cuyo fin es esencialmente extrapatrimonial: la satisfacción de necesidades personales para la conservación de la vida, para la subsistencia de quien los requiere" (p. 47).

\subsection{Características}

\subsection{Es un derecho recíproco}

Es una obligación recíproca en el sentido de que en principio la persona que da los alimentos tiene derecho a recibirlos; en nuestra legislación no existe un precepto que de forma explícita establezca esta reciprocidad 6 , pero la misma se podría deducir de arts., como 73.2 Cn (ya citado); art. 268 Ley 870/20I47.

Esta reciprocidad significa que tanto los progenitores están obligados a alimentar a sus hijos, como los hijos luego pueden verse sometidos a la misma prestación, es decir, ambos tienen vocación a los alimentos; pero hay que advertir que según la sentencia del TS español de 20 de octubre de 1924 "no hay correspectividad y así no es aplicable el art. I I24" [del Código español] (citada por LACRUZ BERDEJO et al., 2005, p. 21 ); equivalente al I 885 de nuestro Código civil. Empero, nuestra legislación se aparta de esta tenencia doctrinal y jurisprudencial al establecer los aspectos a tomar en cuenta para la fijación de la pensión de alimentos en el art. 323 inc. i): "Que los ascendientes hubieren

\footnotetext{
${ }^{5}$ Art. 307 Ley 870/2014: "Prevalencia del derecho de dar alimento. El derecho de alimentos es personalísimo, imprescriptible, irrenunciable, intransigible e intransferible. Los alimentos son inembargables, no son compensables con ningún tipo de deuda. Tendrán, sin excepción, derecho privilegiado y prioridad sobre cualquier otra obligación del alimentante y no podrán ser perseguidos por los acreedores del alimentario.

Art. 314: "La prestación alimentaria es inembargable".

'El crédito alimenticio afectará todo tipo de ingreso, ordinario o extraordinario que se perciba, incluso el décimo tercer mes".

${ }^{6}$ Como por ejemplo el art. 301 del Código civil mexicano que dice: "El que los da tiene a su vez derecho a recibirlos".

${ }^{7}$ Art. 268 Ley 870/2014: "Obligaciones de los hijos e hijas con relación a sus progenitores o quien ejerza la autoridad parental. Los hijos o hijas que sean niños, niñas o adolescentes no emancipados están bajo el cuidado del padre y de la madre, o de quien ejerza autoridad parental, han de seguir sus orientaciones, guardarles respeto y consideración. Los hijos e hijas mayores de edad deberán de asistir al padre y madre o a quien ejerza autoridad parental, en circunstancias adversas y cuando sean adultos mayores, además de contribuir a los gastos familiares. Estos derechos y obligaciones no son excluyentes de los derechos y obligaciones que se encuentren establecidos en los instrumentos y tratados internacionales y demás leyes relacionadas a las niñas, niños o adolescentes, así como a las personas adultas mayores".
} 
cumplido con su obligación derivada de la relación parental". Este precepto draconiano representa una verdadera "Ley del talión" dentro de legislación en materia del alimentos; de manera que si, por ejemplo, el padre no cumplió con sus prestaciones alimenticias para con sus hijos, éstos no estarían obligados a socorrerle en caso ameritar de asistencia de esta índole. En nuestra opinión, no compartimos tal criterio porque los alimentos, al igual que el Derecho de familia, están determinados por una amalgama de normas no solo jurídicas, sino éticas, morales e incluso religiosas (pensemos por ejemplo en la fidelidad en el matrimonio señalada en el art. 80 inc. d); en consecuencia, criterios de orden ético, moral e incluso cristiano, prescriben que un hijo se haga cargo de su padre, aún en el caso de que su progenitor lo haya abandonado, pues es una regla cristiana "poner la otra mejía", es decir, devolver el bien por el mal. Finalmente, cabe destacar que la reciprocidad admite excepciones (MONTERO DUHALT, 1984), como cuando la obligación de prestar alimentos se funda en un acto testamentario (art. I I46 C) 8 o en la donación universal (art. 2775 C) ; "Tampoco se da en los alimentos que tengan por origen un convenio en los cuales se estipula quién será el acreedor y quién será el deudor" (p. 63); pues en este caso “... se trataría de una obligación patrimonial como cualquier otra, no sujeta a los caracteres y condiciones del derecho alimentario, derivado del parentesco (BELLUSCIO, 1985, p. 390).

\subsubsection{Es un derecho personalísimo}

El carácter personalísimo se evidencia porque:

...depende exclusivamente de las circunstancias individuales del acreedor y del deudor. Los alimentos se confieren exclusivamente a una persona particular, en razón a sus necesidades, y se imponen también a otra persona determinada, tomando en cuenta su carácter de pariente, de cónyuge o concubino y sus posibilidades económicas (CHÁVEZ ASENCIO, 2007, p. 472).

Sobre esta particularidad nos dice el jurista BRENES CÓRDOBA (1974):

"Es entendido que la cuantía del suministro se limita a la subsistencia individual del alimentario, no obstante que fuere casado y con hijos, por tratarse de un derecho vinculado a su persona exclusivamente; $y$ aunque sus hijos pudieran tener idéntica facultad para reclamar del mismo alimentante igual asistencia, ya este sería un derecho distinto del de su padre, que habría de discutirse y resolverse aparte" (p. 236).

En este sentido el art. 308 CF establece: Personalísimo. Se entiende por personalísimo el vínculo jurídico entre dos personas, el alimentante y el alimentario.

Este atributo personalísimo explica otros caracteres como la irrenunciabilidad, intransmisibilidad, inembargabilidad, etc.

\subsubsection{Es un derecho no compensable y es un crédito prioritario}

La compensación es una forma de extinción de las obligaciones cuando dos personas son recíprocamente acreedora y deudora. La legislación prohíbe compensar las prestaciones alimenticias; así, el art. 3 I 2 CF establece:

\footnotetext{
${ }^{8}$ Art. 1146 C: "El legado de alimentos comprende la instrucción correspondiente a la condición del legatario, la comida, el vestido, la habitación, la asistencia en las enfermedades hasta la edad de dieciocho años, si no estuviere imposibilitado para poder procurarse los alimentos. Si lo estuviere, el legado durará la vida del legatario".

${ }^{9}$ Art. 2775 C: "El que hace donación de todos sus bienes, podrá reservarse lo necesario para su alimentación, y si omitiere hacerlo, podrá en todo tiempo obligar al donatario a que de los bienes donados, o de los suyos propios, si aquellos no existieren, le asigne a este efecto, a título de propiedad o de usufructo, lo que se estimare competente, habida proporción a la cuantía de los bienes donados".
} 
No compensación, crédito privilegiado y preferente. El juez o jueza no autorizará ninguna forma de compensación de la prestación alimentaría, con ningún tipo de deuda.

La prestación alimentaria será privilegiada y preferente sobre cualquier otra obligación del alimentante aun cuando exista sentencia ejecutada por una deuda anterior"

Esta disposición no deja de ser una ratificación de la regla contenida en la segunda parte del art. 2I 50 C: "Tampoco podrá oponerse compensación a la demanda de indemnización por un acto de violencia o fraude, ni a la demanda de alimentos no embargables".

El carácter privilegiado de esta clase de crédito se fundamenta en que desempeña una función indispensable para la sobrevivencia de menores de edad, personas discapacitadas o en estado de vulnerabilidad. Así en la parte in fine del párrafo del art. 307 CF se lee: “...Tendrán, sin excepción, derecho privilegiado y prioridad sobre cualquier otra obligación del alimentante y no podrán ser perseguidos por los acreedores del alimentario”.

Esta prioridad significa que el crédito proveniente de una obligación alimenticia tiene preferencia sobre cualquier otra deuda del alimentante. Este carácter preferente es de tal magnitud que incluso ni siquiera un funcionario cobijado bajo el manto de la inmunidad goza de tal privilegio en el caso de las obligaciones alimenticias (Párrafo $4^{\circ}$ del art. $130 \mathrm{Cn})^{10}$. En el Código del trabajo vigente también se constata el carácter de prelación que gozan los alimentos, pues se lee en el art. $89 \mathrm{CT}$ :

"El salario, el pago de vacaciones no gozadas, el decimotercer mes y las indemnizaciones por riesgo o accidente de trabajo, gozan de los siguientes privilegios: a) Son preferentes a cualquier otro crédito, excepto los alimentos de familiares del trabajador declarados judicialmente" (Ver también el art. 97 CT) $)^{\prime \prime}$.

En el caso de los bienes constituidos por el fideicomitente en calidad de fideicomiso, podrán ser afectados por demandas de alimentos aunque estén a nombre del fiduciario conforme el art. 45 de la Ley 74I, Ley sobre el contrato de fideicomiso, publicada en La Gaceta Diario Oficial N II de 19 de enero de 20I I, en adelante Ley $74 I / 20 I I^{12}$.

10 Art. 130.4 Cn: "La Asamblea Nacional mediante resolución aprobada por dos tercios de votos de sus miembros podrá declarar la privación de inmunidad del Presidente de la República. Respecto a otros funcionarios la resolución será aprobada con el voto favorable de la mayoría de sus miembros. Sin este procedimiento los funcionarios públicos que conforme la presente Constitución gozan de inmunidad, no podrán ser detenidos, ni procesados, excepto en causas relativas a los derechos de familia y laborales. La inmunidad es renunciable. La ley regulará esta materia".

${ }^{11}$ Art. 97 CT: "El salario correspondiente al décimo tercer mes es inembargable, salvo para el cumplimiento de las obligaciones de prestar alimentos, tiene la misma protección que el salario mínimo, y estará exento del pago de todo impuesto, descuentos, cotizaciones y deducciones de cualquier especie.

12 Art. 45 Ley 741/2011: "Garantía para acciones por Alimentos.

Los bienes muebles fideicomitidos, si están en posesión del fiduciario, así como los inmuebles y derechos reales inmobiliarios fideicomitidos, mientras permanezcan inscritos en el Registro Público a nombre del fiduciario, continuarán siendo la garantía de las obligaciones alimentarias a cargo del fideicomitente.

La demanda de alimentos entablada contra el fideicomitente, se podrá anotar en el Registro Público, al margen de los inmuebles y derechos reales inmobiliarios fideicomitidos, mientras permanezcan inscritos a nombre del fiduciario.

Para asegurar el resultado de la acción de alimentos, son embargables, retenibles, objeto de secuestro o susceptibles de intervención, aun preventivamente, los bienes muebles fideicomitidos, si están en posesión del fiduciario, así como los inmuebles y derechos reales inmobiliarios, mientras permanezcan inscritos en el Registro Público a nombre de éste.

Cuando los bienes muebles, inmuebles y derechos reales hayan sido fideicomitidos en garantía de alimentos a cargo del fideicomitente, la anotación, el embargo, la retención, el secuestro o la intervención obtenidos por el actor de la demanda de alimentos, no perjudicarán los derechos y privilegios del acreedor garantizado. 
Sobre este atributo expresan nuestros magistrados en la S. № 133 de las 8.45 a.m. del 02 de diciembre de 1998 , La Ley de Alimentos fue sustraída del ámbito civil general, la obligación alimentaria al tener características de imprescriptible, irrenunciable e intransferible, se vuelve una obligación especial privilegiada y priorizada, que es normada por una ley especial, de ninguna manera podemos considerar que la obligación alimentaria deviene de una deuda civil que debe ser probada, como pretende hacerlo aparecer el demandado, sino que deviene de normas constitucionales que se complementan con lo mandatado por la Ley I43, Ley de Alimentos... (Corte Suprema de Justicia, 2007, p. 270) ${ }^{13}$.

\subsubsection{Es un derecho intransferible}

Las obligaciones alimenticias son intransferibles y esta peculiaridad se deriva del carácter personalísimo antes referido. "La calidad de cónyuge o pariente son esencialmente personales e intransmisibles" (MONTERO DUHALT, 1984, p. 64); de manera que esta prestación no se transmite y se extingue con la muerte del alimentari; desde la época del ancestral Derecho romano expresaba ULPIANO (D. 2.I5.8.10, citado por DOMINGO \& RODRíGUEZ-ANTOLíN, 2000, PP. 37-38): Constat alimenta cum vita finiri ("Consta que los alimentos terminan con la vida"); es decir, no hay razón para transmitir este derecho por herencia o por cualquier otro medio. En este sentido dispone el art. 3II CF: "Intransferible. Que no puede transferirse a ninguna otra persona el derecho a exigir alimentos".

No obstante, desde el punto pasivo de la obligación, la excepción de la regla de la intransmisibilidad la encontramos en las asignaciones forzosas del art. I $197 \mathrm{C}$ : "Asignaciones forzosos son las que el testador es obligado a hacer, y que se suplen cuando no las ha hecho, aún con perjuicio de sus disposiciones testamentarias expresas.

Son asignaciones forzosas:

$I^{\circ} \quad$ Los alimentos que se deben por la ley a ciertas personas;

Arts. 283-29I C.

$2^{\circ} \quad$ La porción conyugal".

De igual manera se lee en el art. Art. 976 C:

"No hay herederos forzosos. En consecuencia, el testador podrá disponer libremente de sus bienes, sin perjuicio del derecho de alimentos que la ley concede a ciertas personas y de la porción conyugal en favor del cónyugue sobreviviente que carece de lo necesario para su congrua sustentación”.

En este sentido, el párrafo $3^{\circ}$ del art. 329 Cf se señala que: "La ejecución de la sentencia podrá tramitarse contra el o la alimentante, sus sucesores o sus representantes, siempre que la obligación sea”.

\subsubsection{Es un derecho imprescriptible}

El Código de familia establece la imprescriptibilidad de esta clase de obligaciones y esto significa que el derecho a percibir alimentos no prescribe nunca aunque concurriendo todos los requisitos para su ejercicio, el alimentario no lo ejercite (LACRUZ BERDEJO et al., 2005, p. 2I); por ejemplo, si una madre con hijo de 12 años de edad, reclama por primera vez alimentos, el demandado no podría alegar con fundamento la prescripción de 10 años contenida en el art. 905 del Código civil ${ }^{14}$. Con todo, tengamos presente que el Derecho a pedir alimentos no está dentro del comercio de los hombres y de acuerdo al art. 870 del Código civil: "Sólo pueden prescribirse las cosas, derechos y obligaciones que están en el comercio, salvas las excepciones establecidas por la ley”. Lo que sí prescribe son las

\footnotetext{
${ }^{13}$ Aunque esta sentencia se refiera a la ya derogada Ley 143/1992, la cita es válida para resaltar las características de la deuda alimentaria.

${ }^{14}$ Art. 905 C: "Todo derecho y su correspondiente acción se prescribe por diez años. Esta regla admite las excepciones que prescriben los artículos siguientes, y las demás establecidas expresamente por la ley".
} 
concretas pensiones ya vencidas en el término de un año, en este sentido el art. 309 CF reza así: "Siempre está vigente la obligación de dar alimentos, aunque prescriban las pensiones alimenticias atrasadas después de doce meses".

\subsubsection{Es un derecho irrenunciable, inembargable e intransigible}

La irrenunciabilidad refleja que el derecho de alimentos escapa de la libre disponibilidad de las partes; "permitir su renuncia equivaldría a autorizar al sujeto a morirse de hambre" (MONTERO DUHALT, 1984, p. 67); así, por ejemplo, cualquier acuerdo en un trámite de divorcio para renunciar al Derecho a la pensión de alimentos no tendría ninguna validez. Esta característica también ha sido confirmada por la jurisprudencia nacional en S. de las 10:30 am del 4 de abril de 1990, B.J. año 1990, pp. 76-78: "Se reafirma que el derecho de alimento de los menores es irrenunciable" (citada por LEZAMA BALCÁCERES, 2000, p. 29).

Este carácter de irrenunciabilidad del derecho a percibir alimentos proviene “... de que el fin a que se encamina - el sostenimiento de la vida-, reclama de modo necesario que pueda ser alcanzado en cualquier momento en que falten al individuo los medios de subsistencia" (BRENES CÓRDOBA, 1974, p. 237). Además razones de orden público proclaman esta característica:

La renuncia y la consiguiente liberación del deudor harían gravitar la obligación sobre otras personas o sobre la colectividad, haciendo más gravosa a carga de las instituciones de beneficencia, sean públicas o privadas (MeZa Barros, 1995, p. 232).

Bajo esta línea de pensamiento indica el art. 3 I2 CF: "Irrenunciabilidad e Intransigible. No se admitirá ningún tipo de transacción o compensación, que implique renuncia total o parcial del derecho a las prestaciones alimentarias, dado el interés social y derecho público de esta materia".

Este precepto es complementado con las normas civiles que regulan la transacción, de manera que en el párrafo segundo de art. 2I86 C se lee: "También es nula la transacción sobre el derecho de recibir alimentos...". La excepción la encontramos con respecto a las pensiones atrasadas, que además de ser objeto de prescripción también pueden ser objeto de transacción, como bien lo dice la parte in fine del recién citado art. 2186 C: "pero se podrá transigir sobre las pensiones alimenticias ya debidas"15. La justificación de esta permisividad de la ley nos la proporciona la jurista MONTERO DUHALT (1984):

Los alimentos que no se dieron a tiempo, y que obligaron al acreedor a adquirir deudas para poder sobrevivir, deben ser pagados mediante la reclamación judicial que de los mismos haga el acreedor; sin embargo, la transacción no implica peligro para la subsistencia del alimentista puesto que ya los devengó de alguna manera y sobrevivió (p. 69).

En la Ley 540, Ley de Mediación y arbitraje, publicada en La Gaceta, Diario Oficial N 122 del 24 de junio de 2005, en adelante Ley 540/2005, se establece a la prohibición de arbitraje en materia de alimentos (arts. 23.4 Ley 540/2005), en la misma dirección señala el art. $963 \operatorname{Pr}^{16}$.

\footnotetext{
${ }^{15}$ En igual sentido establece el art. 2951 del Código civil mexicano "Podrá haber transacción sobre las cantidades que ya sean debidas por alimentos.

${ }^{16}$ Art. 23 Ley 540/2005: ": "Así mismo, no podrán ser sujetos de arbitraje las cuestiones que versen sobre alimentos; divorcios... nulidad de matrimonio; estado civil de las personas; declaraciones de mayor de edad...".

Art. 963 Pr: "No podrán ser sometidas a las resoluciones de árbitros, las cuestiones que versen sobre alimentos, divorcio, ya sea voluntario o forzoso... nulidad del matrimonio, estado civil de las personas; declaraciones de mayor de edad, y en general, las causas de aquellas personas naturales o jurídicas que no pueden representarse a sí mismas: en estos casos se atenderá a las formalidades prescritas en la ley respectiva para efectuar el arbitramento".
} 
La inembargabilidad, como hemos dicho, se deriva del carácter personalísimo y sui generis de esta clase de prestación y se encuentra consagrada además del arts. como el 3 I 4 del CF (precitado) en normas como el art. I703 inc. 2 Pr.) $)^{17}$.

\subsubsection{Tiene un carácter proporcional}

El quantum de la pensión alimenticia tiene un carácter relativo en función de los ingresos del alimentante y de las necesidades del alimentario ${ }^{18}$. Bajo esta línea doctrina se lee en el art. 306.I CF:

Concepto y cobertura de alimentos. Los alimentos son bienes necesarios que se proporcionan para la vida de una persona. Comprende una prestación económica que guarda la debida relación entre las posibilidades económicas de quien está obligado a darlos y las necesidades de quien deba recibirlos.

Este carácter proporcional también está referido en la parte ab initio del art. 82 CF: Aporte económico de los cónyuges en la familia. Los cónyuges deben sufragar en proporción a sus recursos económicos los gastos de la familia...".

El carácter proporcional también se nota en el caso de que hayan dos o más personas obligadas a cumplir una misma prestación alimenticia; tal situación es contemplada en la parte in fine del art. 316 CF:

Cuando recaiga sobre dos o más personas la obligación de dar alimentos, se repartirá entre ellas el pago de la pensión en cantidad proporcional a sus ingresos y capital. En caso de que la demanda recayera sobre uno de los obligados, este podrá solicitar se amplíe la demanda en contra de los otros obligados.

\subsubsection{Tiene un carácter variable y actualizable}

Como consecuencia de la anterior propiedad, resulta lógico entender que la pensión alimenticia pueda resultar siendo incrementada o reducida según las vicisitudes que pueda afrontar la situación económica del alimentista o la condición del beneficiario, por ejemplo, supongamos que el hijo se recupera de una grave enfermedad y ya no es necesario tantos recursos para gastos médicos. En este sentido, se expresa en la parte final del art. 328 CF: "La sentencia podrá ser modificada cuando cambien las circunstancias de quien los da y las necesidades de quien los reciba"; comentando el tema de las circunstancias, expresan nuestros magistrados del Tribunal Supremo, “... debe alegarse un cambio de circunstancias y no intentar una acción nueva pero idéntica a la anterior" (S. de las I2:00 del 2 de febrero de 1950, B.J. I4968, citada por MoNTIEL ARGÜELLO, 1970, p. 49).

Esto significa que en los juicios de alimentos no puede existir la cosa juzgada (arts. I38, 444 y 539 CF) ${ }^{19}$.

\footnotetext{
${ }^{17}$ Este precepto 1703 inc 2 Pr aunque hace referencia a artículos derogados (art. 286 y 287 C), sirve de referencia para evidenciar el carácter inembargable de los créditos alimentarios.

${ }^{18}$ En este sentido dice nuestra Corte Suprema de Justicia: "En cierto como afirma el recurrente que la obligación de prestar alimentos a los hijos en su triple aspecto de mantener, educar e instruir, incumbe al padre y a la madre en proporción de sus haberes (art. 158 C), y que de conformidad con el art. 284 del mismo Código deber ser proporcionados al caudal del que los debe y a las circunstancias del que los recibe. Resulta entonces que es de prima importancia la demostración de las posibilidades económicas del padre para obligarlo a contribuir, en primer término, y para determinar la cuantía de esa contribución, en segundo término". B. J. 1968, p. 307, Cons. III. (Citado por Citada por HUEMBES Y HuEMBES, 1971, p. 31).

${ }^{19}$ Art. 138 CF: "Pronunciamientos que no gozan de fuerza de cosa juzgada material. Los pronunciamientos en las sentencias de divorcio sobre el cuido y crianza de los hijos e hijas que sean niños, niñas o adolescentes, personas declaradas judicialmente incapaces, la autoridad parental, pensiones alimenticias y pensiones compensatorias, no causan estado. Estas pretensiones en cualquier proceso en que fueren solicitadas, pueden ser modificadas, cuando varíen las condiciones y las circunstancias por las cuales se otorgó el derecho". Art. $444 \mathrm{CF}$ : "Fuerza de cosa juzgada en materia familiar. Algunas sentencias recaídas en los procesos familiares, como los alimentos, cuido y crianza, régimen de visitas
} 
Sobre este tema resulta oportuno el debate que se plantea con respecto a si con la nueva regulación del Código de familia, se podrían incoar demandas de reforma de alimentos; por ejemplo, si un progenitor tiene establecida mediante una resolución judicial una pensión alimenticia del $40 \%$ por un único hijo, cabe preguntarse, si con la nueva legislación ipodría solicitar la reducción de dicho monto en virtud el art. 324 inc. a) de la Ley 870/20I4 al $25 \%$ ? El art. $\mathrm{V}$ inciso o parágrafo $4^{\circ}$ del Título preliminar de nuestro Código civil, parece decantarse por una respuesta positiva ${ }^{20}$; hay que tener presente que ésta es una norma que no ha sido derogada por el Código de familia. El artículo es claro, y haciendo abstracción de lo obsoleto y derogado de la terminología de hijo ilegítimo, es lógico deducir que si en cuanto a su modo de ejercicio y su extinción la pensión de alimentos se va a regular con la nueva ley, se podría concluir que tal precepto permite demandar una reforma de alimentos e incluso su extinción; sobre todo, a la luz de los arts. 138, 444 y 539 CF antes referidos. Empero, un análisis hecho con más detenimiento, nos permite, en nuestra opinión, llegar a una conclusión opuesta; en efecto, el art. 444 CF en su parte final se lee, refiriéndose a la cosa juzgada en materia de familia: "Sus efectos subsisten, en tanto y en cuanto la situación que la motivó no haya cambiado"; es decir, este precepto autoriza la reforma de la pensión alimenticia solo en aquellos casos en que "la situación que la motivó haya cambiado", como por ejemplo, bajo las siguientes causales: el hijo enfermo se recupera; llega a la mayoría de edad; se emancipa; nace otro hijo con una nueva pareja, etc. Por el contrario, no se debería admitir una acción de reforma cuando las circunstancias que originaron la pensión de alimentos se mantengan estables y solo se alegue como motivo la nueva disposición del Código de familia. No obstante, debemos admitir que estas son meras especulaciones y que la praxis judicial tendrá la última palabra.

\subsubsection{Es una obligación de tracto sucesivo}

Esta particularidad implica que las pensiones alimenticias no se extinguen como otras obligaciones de prestación instantáneas o de tracto único con el pago (como la compraventa manual en la que simultáneamente se intercambian bienes y dinero o la cancelación de una deuda mediante un solo pago), sino que, como dice el subtítulo, son obligaciones de tracto sucesivo porque se ejecutan periódicamente mientras subsista tal responsabilidad.

En concordancia con este señalamiento doctrinal se lee en el inciso a) del art. $328 \mathrm{CF}$ :

Pronunciamientos en sentencia. Cuando los alimentos se decidieren en vía judicial, la sentencia además de los requisitos generales establecidos en este Código, expresará: a) El monto de la prestación alimentaría a favor de quien tenga derecho, deberá pagarse y la periodicidad: mensual, quincenal o semanalmente.

\subsection{I0. Es una obligación divisible}

Una obligación es divisible cuando es susceptible de ser descompuesta en varias prestaciones parciales y homogéneas, $y$ es indivisible la obligación que carece de tal singularidad. En este sentido, el art. $1953 \mathrm{C}$ estipula: "Las obligaciones son divisibles cuando tienen por objeto, prestaciones susceptibles de cumplimiento parcial. Son indivisibles, si las prestaciones no pudieren ser cumplidas sino por entero". Resulta evidente que las obligaciones

y comunicación, suspensión de la autoridad parental, tutela, declaración de incapacidad, no tienen la estabilidad propia de la cosa juzgada material tradicional. Sus efectos subsisten, en tanto y en cuanto la situación que la motivó no haya cambiado". Art. 539 CF: Sentencias que no gozan de fuerza de cosa juzgada. Las sentencias sobre alimentos, cuidado personal, suspensión de autoridad parental, tutorías, fijación de regímenes de visitas, deber de convivencia y todas aquellas que no causan cosa juzgada de conformidad al Código de Familia, podrán modificarse de acuerdo a este Código en un nuevo proceso.

${ }^{20}$ Art. V inc. $4^{\circ}$ del Título preliminar del Código civil: "El hijo ilegítimo que hubiere adquirido derecho a alimentos bajo el imperio de una antigua ley, seguirá gozando de ellos bajo la que posteriormente se dictare; pero en cuanto a su modo de ejercicio y a la extinción de este derecho, se seguirán las reglas de la nueva ley". 
alimenticias son divisibles, pues pueden satisfacerse mediante prestaciones periódicas, conforme el recién citado art. 328 inc. a) CF.

\subsection{Los sujetos: alimentante (s) y alimentario (s)}

Como toda obligación, las alimenticias, están compuestas por dos partes: la parte deudora, que es la obligada a proporcionar la pensión; y una parte acreedor, que es la beneficiaria de recibir los alimentos.

Desde que nace el derecho a pedir los alimentos y presupuesto que el obligado tenga capacidad económica para facilitarlos, pueden pedirse entre sí, de acuerdo al 316 CF las siguientes personas:

Se deben alimentos en el siguiente orden:

a) A los hijos e hijas que no han alcanzado la mayoría de edad, a los mayores de edad, hasta que cumplan los veintiún años de edad, cuando estén realizando estudios, siempre que no hayan contraído matrimonio, ni se hayan declarado en unión de hecho estable y no estén laborando, y a las personas con discapacidad. Los concebidos y no nacidos, se consideran personas menores de edad;

b) El o la cónyuge o conviviente mientras no tenga para su congrua sustentación;

c) A los hermanos y hermanas, a los ascendientes y descendientes hasta el segundo grado de consanguinidad, cuando se encuentren en estado de necesidad o desamparo. Si la persona llamada en grado anterior a la prestación no estuviera en condiciones de soportar la carga en todo o en parte, dicha obligación será puesta en todo o en parte a cargo de las personas llamadas en grado posterior.

Un aspecto novedoso y positivo que establece el Código de familia, es la obligación alimenticia para los nasciturus, regulado en el art. 319; aunque esta norma señala una presunción iuris tantum (que admite pruebe en contrario) sobre la paternidad:

Derecho a demandar alimentos antes del nacimiento del hijo o hija. La madre podrá solicitar alimentos para el hijo o hija que está por nacer cuando éste hubiese sido concebido antes o durante los doscientos sesenta días a la separación de los cónyuges o convivientes, salvo prueba en contrario la que se tramitara como incidente.

No sabemos la intención de legislador al establecer ese período de 260 días, porque el plazo promedio de duración de un embarazo es de 9 meses equivalentes a 270 días o 40 semanas equivalentes a 280 días, la cifra tal vez se deba a un lapus calami de nuestros diputados y donde pusieron 260 días habrán querido decir 270 o 280.

En las circunstancias bajo las cuales los hijos no estén reconocidos, se puede tramitar un reconocimiento ante una autoridad judicial regulado en el art. 2I4 CF: "Reconocimiento judicial. Es el reconocimiento no voluntario, que es ventilado ante los juzgados de familia y donde no hubieren, serán competentes los jueces y juezas de los juzgados locales de lo civil y locales únicos”.

\subsection{Obligados conforme al Derecho de familia}

Las personas legitimadas para reclamar alimentos lo pueden hacer por sí mismas o por medio de un representante legal (art. $322 \mathrm{CF})^{21}$. Entre ellas señalamos las siguientes:

a) Padre e hijos: el padre y la madre están obligados a satisfacer las necesidades alimenticias de su prole; esta obligación subsiste aunque recibieran ayuda de algunos de los ascendientes inmediatos; por ejemplo,

${ }^{21}$ Art. 322 CF: "Personas legitimadas para reclamar alimentos. Podrán demandar alimentos los que estén llamados por Ley a recibirlos, bien por sí, o por medio de un representante legal, si no gozaren del pleno ejercicio de su capacidad jurídica". Entiéndase la capacidad de obrar, capacidad de ejercicio o capacidad legal. 
no se puede admitir que el padre de los menores de edad se excuse de su obligación argumentando que los padres de la esposa la ayudan. En este sentido expresa la jurisprudencia mexicana: "Si los alimentos son pedidos judicialmente por la mujer a su esposo, el demandado no puede alegar en contrario que la acreedora recibe la ayuda económica de sus padres, porque la obligación de pagar o ministrar a la mujer casada recae en el cónyuge y no en los padres de aquélla" CHÁVEZ ASENCIO, 2007, p. 482)22. La obligación de prestar alimentos entre padres y madre a hijos está normada por varios preceptos entre ellos los arts. $73.2 \mathrm{Cn}$; arts. I88, 274 inc. b., 276 y especialmente el 316 inc. a., todos de Ley 870/20I4; art. 24 Ley $287 / 1998)^{23}$. El inciso a) del art. 316 recién citado, señala la obligación de los progenitores para con sus hijos de asistirles con alimentos hasta que éstos cumplan la mayoría de edad (I 8 años art. 21 inc. a., Ley $870 / 2014$ ); y en caso de que estén realizando estudios ${ }^{24}$, se prorroga hasta los 21 años ${ }^{25}$. El incumplimiento de los deberes esenciales de los progenitores con respecto a sus hijos, puede dar lugar al juicio de declaración judicial de estado total de desamparo señalado en el art. 31 de la Ley 287/199826. Como es una obligación recíproca, por su parte los hijos están obligados a mantener a su padre y madre, como hemos visto.

b) Los cónyuges entre sí: el mutuo auxilio referido en el art. 80 inc. c Ley 870/2014) ${ }^{27}$, se refiere, entre otras cosas, al deber de prestar alimentos entre los cónyuges. Cabe destacar que según los arts. 159, 163 inc. d), 164.2, 177, entre otros, indican que se debe pagar una pensión compensatoria al cónyuge aun en caso de ruptura del vínculo matrimonial". La pensión matrimonial compensatoria es una "Consecuencia de los perjuicios económicos derivados de separación o del divorcio y también de la declaración de nulidad matrimonio en caso de buena fe" (DEL ARCO TÓRREZ, M. A., et al., 2004, p. 394). La sentencia Tribunal Supremo (STS) español de 17 de junio de 1972 parece responder afirmativamente a la posibilidad de que sí se pueden pedir alimentos entre cónyuges sin estar entablada o, en su caso, resuelta la causa de separación entre los mismos” (citada por LACRUZ BERDEJO et al., 2005, p. 22). Nuestra legislación familiar

\footnotetext{
${ }^{22}$ Amparo directo 4278/1973. Lamberto Martínez Nieto. Junio 24 de 1974. 5 votos. Ministro: Enrique Martínez Ulloa, $3^{a}$ Sala, Séptima Época. Volumen 66. Cuarta parte, p. 15 (Visible en Ediciones Mayo. Actualización IV, p. 137).

${ }^{23}$ Art. 73.2 Cn: "Los padres deben atender el mantenimiento del hogar y la formación integral de los hijos mediante el esfuerzo común, con iguales derechos y responsabilidades. Los hijos, a su vez, están obligados a respetar y ayudar a sus padres. Estos deberes y derechos se cumplirán de acuerdo con la legislación de la materia". Art. 77: "Los ancianos tienen derecho a medidas de protección por parte de la familia, la sociedad y el Estado". (art. 268 Ley 870/2014).

Art. 24 Ley 287/1998: "Es obligación de las madres y de los padres, la responsabilidad compartida, en el cuido, alimentación, protección, vivienda, educación, recreación y atención médica física y mental de sus hijas e hijos conforme la Constitución Política, el presente Código y las leyes vigentes".

${ }^{24}$ La norma anterior requería que estén "realizando de manera provechosa" los estudios art. 8 Ley 143/1992)

${ }^{25}$ Cabe destacar que en el anteproyecto de la Ley 870/2014 se establecía los 24 años de edad como límite, cuando el alimentario realizara estudios, luego se rebajó a 22 y finalmente quedó en 21 años; no sabemos qué habrá motivo al legislador a actuar con tal proceder; pero no podemos soslayar que a los 21 años muchos estudiantes aún no han concluido sus estudios universitarios sobre todos en carreras extensas como medicina que cuyos pensum obligan a los estudiantes a hacer, además de sus años de clases, un servicio social de dos años. En similar sentido expresa el Magistrado Aguilar García (s.f, p. 9): "El Cese de la Pensión de Alimentos en los casos de los hijos mayores de edad que se encuentran estudiando el código, establece que es a los 21 años, esta disposición debe aplicarse con mucho cuidado, ya que existen en la realidad casos en que hay carreras profesionales que por su extensión va a ser difícil que el joven culmine a los 21 años, así mismo, puede existir problemas de orden económico, salud, etc., que deben ser valorados para aplicar este límite de edad regulado en la norma".

${ }^{26}$ Art. 31 Ley 287/1998: "Se considera a la niña, niño o adolescente en estado de total desamparo cuando le falte, por parte de sus madres, padres o familia, la alimentación, la protección y cuido que le afecte material, psíquica o moralmente.

La situación de total desamparo en que se encuentre cualquier niña, niño y adolescente deberá ser declarada judicialmente, previa investigación hecha por el equipo interdisciplinario especializado de la autoridad administrativa.

${ }^{27}$ Art. 80 inc. c Ley 870/2014: "Obligaciones de los cónyuges. La mujer y el hombre unidos en matrimonio comparten la responsabilidad de conducción y representación de la familia. Están obligados de manera recíproca a: ... inc. b) Proporcionarse alimentos uno a otro.
} 
va más allá y reconoce el derecho a recibir alimentos aunque los cónyuges o conviviente no estén separados (art. $317 \mathrm{C})^{28}$. Sobre las pensiones entre los esposos establece nuestra jurisprudencia: "Aunque esté demostrado que un cónyuge tiene deudas, si tiene su trabajo propio del cual deriva su subsistencia, no cabe concedérsele alimentos" (S. de las 10:00 am del 27 de febrero de I97I, B.J. 34/I97I, Cons. III, citada por MONTIEL ARGÜELLO, 1977, p. 10).

c) Entre concubinos: se debe brindar alimentos al compañero de unión de hecho estable de igual manera que los cónyuges están obligados a socorrerse entre sí, según acabamos de ver (art. 90 Ley 870/20l4) ${ }^{29}$; esta disposición no es más una secuencia del art. 72 de la Cn que al inicio dice: "El matrimonio y la unión de hecho estable están protegidos por el Estado...".

d) Entre otros parientes: la obligación que puedan tener otros familiares se inserta dentro del parentesco

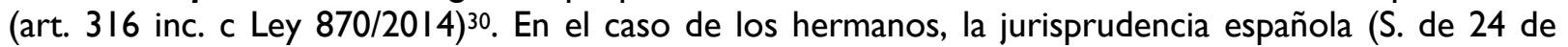
diciembre de 1940, citada por DíEZ PICAZO Y GULLÓN, 2002, p. 57) establece "Los alimentos entre hermanos son alimentos reducidos (auxilios necesarios para la vida) y su constitución se encuentra restringida (necesidades por causa que no sean imputables al alimentista)"; consecuentemente, entre hermanos, por ejemplo, no están autorizados a pedirse dinero para estudios, pues este es un rubro reservado en principio para menores de edad; así lo expresan los juristas BOSSERT y ZANNONI (2008, p. 46) citando el art. 372 del Código civil argentino: "Se trata de un deber asistencia acotado a lo que el pariente mayor de edad requiera exclusivamente para la subsistencia, habitación y vestuario correspondiente a su condición y lo necesario para la asistencia en las enfermedades". Debemos destacar que una de las novedades positivas introducidas por el Ley 870/2014 es el reconocimiento explícito de las obligaciones alimenticias entre hermanos ${ }^{31}$. También se puede concebir que si el pariente más cercano no está en condiciones de prestar alimentos, la obligación la asuma el familiar más próximo; por ejemplo, si los progenitores no pueden asumir sus obligaciones alimentarias (por ausencia, enfermedad o muerte), tal prestación podría ser contraída por los abuelos o por otros parientes cercanos que estén en condiciones de brindarlas (aplicación analógica de este art. 316 inc. c) Ley 870/CF). Finalmente, volvemos recurrir a los juristas recién citados, quienes nos explican que para la procedencia de esta pensión de alimentos para los parientes es necesario demostrar la necesidad o falta de medios, por ejemplo, la existencia de una jubilación o de bienes de capital (aunque no produzcan renta) son incompatibles con el estado de necesidad; también es necesario la imposibilidad de obtener los medios de subsistencia con el trabajo y señalan que "No bastará la falta de trabajo, sino que habrá de acreditarse la imposibilidad de obtenerlo, sean por impedimentos físicos, por razones de edad, salud, etcétera” (BOSSERT \& ZANNONI, 2008, p. 5I).

${ }^{28}$ Art. 317 Ley 870/2014: "Derecho a demandar alimentos aunque los padres no estén separados.

El o la cónyuge o el o la conviviente, podrán demandar alimentos para sí y sus hijos e hijas y mayores discapacitados, aunque no se encuentren separados".

${ }^{29}$ Art. 90 Ley 870/2014: "Derechos y deberes del matrimonio aplicable a la unión de hecho estable. Las disposiciones de este Código relativas a los deberes y derechos que nacen del matrimonio, al régimen económico matrimonial; así como lo relacionado a la filiación y al derecho de alimentos, son aplicables para la unión de hecho estable".

${ }^{30}$ Art. 316 inc. c Ley 870/2014: "Del orden en que se deben los alimentos. Se deben alimentos en el siguiente orden:.. c) A los hermanos y hermanas, a los ascendientes y descendiente hasta el segundo grado de consanguinidad, cuando se encuentren en estado de necesidad o desamparo. Si la persona llamada en grado anterior a la prestación no estuviera en condiciones de soportar la carga en todo o en parte, dicha obligación será puesta en todo o en parte a cargo de las personas llamadas en grado posterior".

${ }^{31}$ En la anterior legislación, regulada por la Ley 143/1992 de forma explícita y entre parientes distintos de los hijos, solo se establecía la obligación entre los ascendientes y descendientes en su art. 7: "También se debe alimentar a los ascendientes y descendientes del grado de consanguinidad más cercano cuando se encuentren en estado de desamparo". 


\subsection{Contenido}

El término alimentos no solo hace referencia a la comida propiamente dicha, sino que como bien lo señala en su tercera definición el Diccionario de la Real Academia Española de la Lengua, la palabra alimento significa: "Cosa que sirve para mantener la existencia de algo..." (DICCIONARIO RAE, 200 I, p. III). En consecuencia, el art. 306.2 CF establece:

Además de las necesidades alimenticias propiamente dichas, se considera también como alimentos, los servicios necesarios para garantizar una mejor calidad de vida, tales como:

a) Atención médica y medicamentos, rehabilitación y educación especial, cuando se trate de personas con alguna discapacidad independientemente de su edad;

b) Vestuario;

c) Habitación;

d) Educación y aprendizaje de una profesión u oficio;

e) Culturales y de recreación.

Por esta razón, como dicen los jurista DíEZ-PICAZO y GULLÓN (2002, p. 52), “... pese a su nombre, la obligación de alimentos comprende un conjunto de prestaciones que cuya finalidad no es sólo la estricta supervivencia, también busca una mejor inserción social (educación y e instrucción)".

En similares términos se expresa el jurista BRENES CÓRDOBA (1974), para quien la palabra alimento tiene un significado que va más allá que el de substancias nutritivas o comestibles, que ordinariamente asume, pues implica, a más de los necesario para el sustento del cuerpo, el vestido, la habitación y los medios para recuperar la salud. Alimentos son, por lo tanto, las asistencias que se dan a alguna persona para su alimentación. Además, cuando el beneficiario sea un menor, dentro del concepto de alimentos entra también los recursos que se necesitan para su instrucción elemental y el aprendizaje de un arte u oficio (p. 235).

Dentro de la prestación alimentaria se incluyen gastos ordinarios y extraordinarios,

"Los primeros son los de subsistencia, habitación y vestuario. Los gastos extraordinarios son los de enfermedades - asistencia médica, gastos de farmacia, intervenciones quirúrgicas, internación, etc.-, los funerarios por sepelio del alimentado, gastos de mudanza, provisión de libros de estudio y litisexpensas. En cambio, no se comprenden los gastos superfluos o impuestos por el lujo, la prodigalidad o el vicio, ni los de establecimiento o constitución de dote (BELLUSCIO, 1985, p. 389).

\subsection{Cuantía y criterios de valoración de la prestación alimenticia}

Para una correcta determinación del quantum de la obligación de dar alimentos es necesario que recordemos ciertos elementos de esta prestación que ya de antemano se han señalado.

Así, en primeramente, hemos constatado que de arts. como el 306.I CF, se deriva que la cuantía de este tipo especial de obligaciones se define en función de los recursos económicos de quien los debe y según de las necesidades del alimentario; esto significa que para determinar sus posibilidades económicas se tomarán en cuenta todos los bienes y todos los ingresos que tenga, es decir, no solo debe valorarse el sueldo sino toda clase de renta que obtenga por inversiones, propiedades, acciones, etc. (CHÁVEZ ASENCIO, 2007, p. 490).

Cabe recordar también que la pensión alimenticia tiene un carácter variable y actualizable (parte in fine del art. 328 CF); es decir, puede aumentar o disminuir en función de las circunstancias, por ejemplo, si contrae una 
enfermedad grave, es lógico que aumenten; por el contrario, disminuirían en caso de que cese sus estudios y deje de asumir los costos de la educación; pero también ese aumento o disminución tiene una relación directamente proporcional con los medios del alimentante, en el sentido lógico de aumentar o mermar la pensión si incrementan o bajan los recursos del deudor obligado sufragar la prestación de alimentos (ALBALADEJO, 2002, p. 17). También estas variaciones están sujetas a las alteraciones del estado económico del alimentario, de manera que si, por ejemplo, el menor de edad hereda una cuantiosa fortuna, sus requerimientos alimenticios disminuirían, porque necesariamente los bienes propios del acreedor de la pensión alimenticia deben ser tomados en cuenta, ya que ayudan al sostenimiento económico; por tanto, deben se restados del monto que en tal concepto se paga en virtud de los alimentos.

No olvidemos que para una correcta medición del monto de la pensión, el concepto mismo de alimento no solo denota las substancias bebidas y comestibles, sino que también abarca una amplia gama de otras necesidades como vestuario, habitación, atención médica y hospitalaria; y a los menores de edad los gastos de educación para proporcionarles un oficio, arte o profesión; para las personas discapacitadas o en estado de interdicción, lo necesario para su recuperación; por último, para los adultos mayores que carezcan de capacidad económica, lo necesario para su atención geriátrica (CHÁVEZ ASENCIO, 2007, p. 489).

Otro elemento digno de tomar en cuenta con respecto a los criterios determinantes de monto pecuniario de la pensión alimenticia, consiste en la relación inversamente proporcional entre la cuantía de la prestación y el número de obligaciones de esta índole que graven el peculio del alimentante; de manera que resulta lógico que si el deudor tiene que mantener por ejemplo a sus padres, a su ex cónyuge u otros hijos con otras parejas, pues la prestación se reduciría en términos cuantitativos. En este sentido dice el jurista BRENES CÓRDOBA (1974), "De un lado, la obligación de asistencia tiene que condicionarse a los medios con que cuenta el obligado, deducidos sus propios gastos y los preferentes de familia" (p. 236).

Por otra parte, de la divisibilidad de esta clase de obligaciones (en el sentido de que son cumplidas mediante prestaciones periódicas mensuales, quincenales o semanales) no hay que concluir su parcialidad, es decir, los alimentos no pueden imponerse parcialmente, por ejemplo, no puede darse solo lo relativo a la alimentación o lo concerniente a la habitación; de aquí que el deudor alimentario no puede satisfacer su obligación con un cumplimiento parcial.

Debemos tomar en cuenta que la pensión alimenticia no es solo de supervivencia, o sea, la parte pasiva de este vínculo jurídico no solo está obligada a dar lo indispensable, sino a dar lo necesario, a lo que están acostumbrados según la forma de vivir de los acreedores alimenticios, que corresponde a la posición económica que ostente el acreedor (CHÁVEZ ASENCIO, 2007, p. 490).

El arbitrio del órgano encargado de la administración de la justicia debería decisivo para la fijación de la cuantía de esta clase de prestación, de manera que se le deberá aportar el juez o jueza las pruebas y los elementos necesarios para una correcta determinación.

En el art. 323 CF se lee:

Aspectos a tomar en cuenta para fijar la pensión. La autoridad competente, para fijar la pensión alimenticia, deberá tomar en cuenta los siguientes aspectos:

a) El capital o ingresos económicos del alimentante;

b) Su último salario mensual y global. Si la o el alimentante renuncia a su trabajo para no cumplir con su obligación, el último salario mensual será la base para fijar la pensión;

c) Si la o el alimentante trabajare sin salario fijo o no se pudiere determinar sus ingresos, el juez o jueza en su caso, hará inspección en sus bienes y determinará la renta presuntiva; 
d) La edad de los hijos e hijas;

e) La situación de discapacidad del niño, niña o adolescente;

f) Si él o la alimentante padece una enfermedad crónica;

g) El estado de necesidad y desamparo de otros alimentistas;

h) Los gastos personales del o la alimentante, quien en ningún caso, podrá evadir las responsabilidades de cumplir con la pensión;

i) Que los ascendientes hubieren cumplido con su obligación derivada de la relación parental.

Una importante novedad que introduce este cuerpo de leyes es la tendencia hacia la objetivación de las pensiones alimenticias, puesto que antes dependía del criterio subjetivo del órgano judicial. En cambio, ahora la forma de tasar las pensiones de alimentos nos la proporciona el art. 324 CF en los siguientes términos:

Formas de tasar los alimentos. El monto mínimo de una pensión alimenticia para un mismo beneficiario, en caso que el alimentista no tenga trabajo estable no podrá ser inferior al veinticinco por ciento del salario mínimo del sector económico a que pertenezca su profesión u oficio. En caso de que el alimentante tenga un trabajo estable se debe tasar los alimentos de la siguiente forma y orden:

a) Veinticinco por ciento de los ingresos netos si hay solo un hijo;

b) Treinta y cinco por ciento de los ingresos netos si hay dos hijos;

c) Cincuenta por ciento de los ingresos netos si hay tres o más hijos y se distribuirán de manera equitativa;

d) Si él o la alimentista tiene más hijos o hijas de los que están demandando alimento, este debe probar que está proveyendo a los demás con alimento, los que deberán ser incluidos en el máximo del cincuenta por ciento;

e) Cuando reclamen alimentos personas distintas a los hijos o hijas, se estipulará un diez por ciento de los ingresos netos adicional, espetando el orden de prelación establecido en el presente Código;

f) En caso de que concurran a reclamar alimentos más de tres hijos y otros alimentistas, el cincuenta por ciento será destinado para los hijos y el diez por ciento se prorratea entre los otros reclamantes.

El límite máximo de pensión alimenticia asignada cuando concurran los incisos anteriores, no podrá ser mayor del sesenta por ciento de los ingresos netos del alimentista, distribuido con equidad entre los demandantes y no demandantes, con prelación a los hijos e hijas.

Sobre esta norma conviene hacer las siguientes acotaciones: en primer lugar debemos discernir aquellos casos en que el deudor de alimentos carece o goza de ingresos fijos producto de un trabajo estable; en el primer caso, conforme la parte $a b$ initio de este art. $324 \mathrm{CF}$, el juez conserva su facultad discrecional, pues el precepto establece un umbral al indicar que el monto de la pensión no podrá ser menor del $25 \%$ del salario mínimo al que pertenezca su oficio o profesión. En cambio, en el caso de contar con ingresos estables, queda claro que al prefijar porcentajes en los montos de las pensiones de alimentos en función del número de hijos e hijas que se tiene, el órgano judicial pierde esa potestad discrecional que es decisiva para una correcta aplicación de la justicia; de manera que, estos porcentajes sin unos correspondientes factores de corrección, que permitan aumentarlos o disminuirlos, se incrustan en el judicial como una camisa de fuerza y le anulan su facultad de tomar decisiones justas en casos particulares, como por ejemplo cuando un menor de edad requiera cuidados especiales fruto de un enfermedad grave con tratamientos costosos. Parece seguir nuestra línea de pensamiento el Magistrado AGUILAR GARCÍA (s.f.) al expresar

b.- La tasación de la Pensión Alimenticia es uno de los logros más importantes de este tema en el Código, ya que en gran medida va a evitar la aplicación discrecional de las Pensiones Alimenticia, sin embargo, esto no excluye que existan casos en que debe valorarse responsablemente y minuciosamente los criterios para tasar la pensión de alimentos que regula el artículo 323 del mismo código (p. 9). 
Nuestra tradición jurídica también se ha decantado por preservar esta potestad discrecional del órgano judicial para fijar la cuantía de la prestación; así en S. de las 9:00 am del 19 de agosto de 1957, B.J 18645, Cons. III se dice: "Es potestativo de los Jueces y Tribunales de instancia fijar el monto de los alimentos y la forma de prestarlos" (citada por MONTIEL ARGÜELlO, 1970, p. 59). Bajo esta misma línea de pensamiento, expresa la jurista mexicana MONTERO DUHALT (1984, p. 62),

... la determinación de la cuantía de la obligación alimentaria es cuestión que queda sujeta a la apreciación del juzgador, sin que puedan señalarse de antemano, las circunstancias que deban tomarse en consideración, porque ésta son diversas en cada caso. La ley solo puede establecer principios generales al respecto.

Por otra parte, consideramos que tales porcentajes pueden ser ponderados por el judicial según las circunstancias; así, imaginemos el caso de dos hijos de un mismo progenitor con distintas madres, uno que requiera cuidados especiales y otro sano; ise distribuirán el 35\% entre cada uno en partes iguales, a razón del $17.5 \%$ per cápita? Ante este injusto panorama, consideramos que lo más apropiado es facultar al judicial para que pueda establecer porcentajes no necesariamente iguales, sino, por ejemplo, de $20 \%$ para uno de los vástagos y un $15 \%$ al otro o $25 \%$ y $10 \%$, basado en la distribución equitativa que habla la parte in fine del inciso c) de este art. 324 CF; tomando en consideración que lo equitativo no significa por antonomasia partes iguales, sino que implica “... dar a cada uno lo que merece" (Diccionario RAE, 200I, p. 943).

Por otra parte, esta misma regla, puede originar dificultades de orden práctico; supongamos el caso de dos madres que demandan al mismo progenitor por un hijo cada una; hemos visto que por dos vástagos ambas recibirían en circunstancias normales la mitad del 35\% (art. 324 inc. b CF) a razón de 17.5\% para cada una; pero puede ser que cada madre de buena o mala fe, reclame el $25 \%$ para cada uno de sus hijos, fundamentadas en el inciso a) de mismo precepto ante jueces distintos. En estos casos, cada juez podría establecer una pensión del $25 \%$ para cada niño, si el demandado no alega la existencia o tramitación de una pensión de alimentos para el otro menor de edad; $y$, en aquellos casos que no reciba una adecuada asistencia legal y sea condenado al pago de dos pensiones de alimentos cada una por el $25 \%$ de sus ingresos, aun conservaría una acción de modificación o reforma de pensión de alimentos ( parte in fine del art. $328 \mathrm{CF}$ ante citado).

\section{8.- Generalidades de la pensión de alimentos}

Entre los tópicos dignos de destacar en la legislación de la familia señalamos los siguientes: se permite el acuerdo notarial en escritura pública sobre la pensión de alimentos, pero deberá ser aprobado por la autoridad administrativa o judicial competente (art. $326 \mathrm{CF})^{32}$. También se puede pagar en parte la pensión de alimentos en especie o con ciertos derechos reales como el usufructo, uso o habitación (art. $327 \mathrm{C}$ ) 33 . Otro ítem digno de resaltar es la potestad que tiene el órgano judicial para supervisar el buen uso de la pensión compensatoria y de la pensión de alimentos (art. $333 \mathrm{CF})^{34}$. También consideramos muy oportuna la norma que indica que basta la

\footnotetext{
${ }^{32}$ Art. 326 CF: "Acuerdo sobre la pensión alimenticia ante notaria o notario público El padre y la madre podrán mediante escritura pública, celebrar acuerdo sobre la pensión de alimentos que se debe pasar al hijo, hija o persona con discapacidad, pero ésta deberá ser ratificada por autoridad administrativa o judicial competente del domicilio del beneficiario, de conformidad con el presente Código".

${ }^{33}$ Art. 327 CF: "Otras formas de pago de la pensión alimenticia. Se podrá autorizar parte del pago de la obligación alimenticia, en especie o en cualquier otra forma, cuando a juicio prudencial del juez o jueza hubiere motivos que lo justificaren.

El beneficiario alimentario o su representante, podrá solicitar la constitución de un usufructo, uso o habitación sobre cualquier bien inmueble del obligado.

34 Art. 333 CF: "Derecho de supervisión del uso de pensión alimenticia o compensatoria

El juez o jueza de familia, de oficio o a petición de parte, podrá comprobar el correcto uso de la pensión alimenticia o compensatoria asignada, tomando las providencias necesarias para corregir cualquier desvío o anomalía en su aplicación y utilización.

En ningún caso podrá suspenderse la obligación de enterar la pensión alimenticia
} 
presentación del acta o la certificación de la sentencia para que el empleador esté obligado a deducir la pensión fijada por la autoridad judicial o administrativa sin necesidad de oficios o procesos de ejecución de sentencia (parte final del art. 329 CF) ${ }^{35}$. El contenido de la sentencia nos lo proporciona el art. $328 \mathrm{CF}^{36}$. Se puede garantizar el pago de pensiones de alimentos (art. 459 CF) ${ }^{37}$; por ejemplo con fianza, hipoteca, prenda o depósito de cantidad bastante para cubrir los alimentos. Cuando hay retraso en el pago de pensiones de esta clase, se puede demandar hasta 12 meses retroactivos (art. 313 Ley 870/2014) ${ }^{38}$. Sobre estos alimentos no pagados, dice nuestra Corte Suprema en S. de las 9:45 am del 4 de agosto de 1970 B.J. I75/ I 970 Cons. III: "No procede la demanda de alimentos pasados sino se alega haber contraído deudas para subsistir" (Citada por MONTIEL ARGÜELLO, 1977, p. 10) y también se aclara que "Para reclamar alimentos pasados no es necesario demostrar la imposibilidad de cobrarlos con anterioridad" (S. de las 10:00 am del 27 de febrero de 197I, B.J. 34/I97I, Cons. V, (Citada por MONTIEL ARgüELLO, 1977, p. 10). En los casos de pluralidad de garantías nuestros magistrados de la Corte Suprema, sostienen que no hay preferencia de una sobre la otra,

Pueden admitirse hipoteca y fianza para garantizar conjuntamente los alimentos..., sin que por ello pueda haber preferencia de una garantía sobre la otra, pues debe hacerse efectiva aquella que, en el instante acordado por la ley, facilite la obtención de los alimentos que garantiza. No cabe, pues, el beneficio de excusión (B.J 1954, p. 16809, Cons. I, citada por HUEMBES \& HUEMBES, I97I, p. 28).

\subsection{Vías legales para exigir el cumplimiento de la pensión alimenticia}

El Código de familia establece las vías administrativa y judicial para reclamar los alimentos conforme el art. 32I que señala:

Vía para reclamar alimentos. Se podrán reclamar alimentos en la vía administrativa o judicial, conforme lo establecido en el Libro Sexto de este Código; o adoptar el acuerdo de prestación alimenticia en sede notarial". Esta vía judicial se escinde en proceso de familia y penal.

a) Proceso administrativo: regulado por la Ley 870 , en los art. 434 y 562 y ss; esta norma establece un procedimiento conciliatorio administrativo ante las autoridades del Ministerio de la familia, con la finalidad

\footnotetext{
${ }_{35}$ Parte in fine del art. 329 CF: "El empleador o la empleadora está obligado a deducir la pensión fijada por la autoridad administrativa o judicial respectiva, con la sola presentación del acta o certificación de la sentencia, bajo pena de cancelarla personalmente y en caso de no hacerlo, queda sujeto a la sanción establecida por el Código Penal".

36 Art. 328 CF: "Pronunciamientos en sentencia

a) Cuando los alimentos se decidieren en vía judicial, la sentencia además de los requisitos generales establecidos en este Código, expresará:

b) El monto de la prestación alimentaría a favor de quien tenga derecho, deberá pagarse y la periodicidad: mensual, quincenal o semanalmente;

c) La afectación de los ingresos que perciba el alimentante;

d) La autorización para el pago de la obligación alimentaría en especies o en cualquier otra forma, cuando a juicio prudencial del juez o jueza hubiere motivos que lo justifiquen;

e) Ordenar medidas de protección o la continuación de las ya existentes;

f) Monto de los alimentos atrasados y forma de pago.

La sentencia podrá ser modificada cuando cambien las circunstancias de quien los da y las necesidades de quien los reciba".
}

${ }^{37}$ Art. 459 CF: "Clases de medidas cautelares

Las medidas cautelares a que se refiere el artículo anterior, entre otras, pueden ser.... g) Constitución de garantía sobre bienes o derechos que aseguren el pago de la prestación.

${ }^{38}$ Art. 313 CF: "Retroactividad

El pago de prestaciones alimentarias podrá reclamarse retroactivamente hasta pordoce meses, correspondiendo la carga de la prueba al alimentante". 
que las partes obtengan una respuesta expedita y gratuita ${ }^{39}$; la Ley $287 / 1998$ en su art. 89 también señala esta facultad de las autoridades administrativas de resolver las disputas alimenticias ${ }^{40}$.

b) Proceso penal: Debido a la sensibilidad que el tema de alimentos tiene, el legislador lo ha tipificado como un delito penal en la Ley 64I, Código penal (art. 217 Cp). La ventaja que tiene este proceso es que es relativamente expedito y una vez detenido el moroso incumplidor, por lo general, se paga inmediatamente la deuda para evitar la continuación del presidio. Cabe destacar que el mismo Código de familia remite al Ministerio Público los casos de incumplimiento de prestaciones alimenticias (art. $330 \mathrm{CF}$ ) ${ }^{41}$. Cabe señalar que para la procedencia de esta acción penal es necesario que la obligación esté asentada en un documento que preste mérito ejecutivo como acuerdo de mediación suscrito ante el Ministerio de la Familia o ante un centro de mediación acreditado por la DIRAC, así como también se puede derivar del incumplimiento de una resolución judicial que ordene el pago de alimentos.

c) Proceso de Derecho de familia: de conformidad con el art. 425 inciso e) de la Ley 870/20/4, las disposiciones del presente libro se aplicarán a los procesos de alimentos. Estos casos, según el art. 429 CF, se tramitarán ante los jurisdicción especializados de familia en la Corte Suprema de Justicia, Tribunales de apelaciones, juzgados locales o de Distrito de familia y en su defecto por juzgados civiles; el procedimiento está regulado en el Libro Sexto arts. 425 y ss; la ventaja de este proceso es que mientras se tramita el juicio el o la juez puede ordenar el pago de pensión provisional (art. 459 inc. d Ley 870/2014).

\section{I0. Incumplimiento de la prestación alimenticia}

El incumplimiento de la obligación de brindar alimentos constituye un ilícito penal tipificado en el título V: "Delitos contra la familia", Capítulo III: "Incumplimiento de deberes familiares", art. 217: "Incumplimiento de los deberes alimentarios:

Se impondrá pena de prisión de seis meses a dos años e inhabilitación especial por el mismo período para ejercer los derechos derivados de la relación padre, madre e hijos, guarda o tutela a:

a) Quien estando obligado a prestar alimentos conforme la ley de la materia, mediando resolución provisional ○ definitiva u obligación contractual, $\circ$ mediante acuerdo ante cualquier organismo $\circ$ institución, deliberadamente omita prestarlos;

b) Quien estando obligado al cuidado o educación de otra persona, incumpla o descuide tales deberes, de manera que ésta se encuentre en situación de abandono material o moral.

39 Art. 434 CF: "Conciliación en vía administrativa. En el ámbito administrativo, el Ministerio de la Familia, Adolescencia y Niñez podrá intervenir en los asuntos familiares sujetos a su competencia por vía conciliatoria, a objeto de lograr acuerdos o compromisos entre las partes, como espacio de avenimientos a sus conflictos, previo al proceso judicial. Los acuerdos alcanzados constarán en actas firmadas por los sujetos intervinientes y tendrán fuerza ejecutiva para estos, cuya ejecución puede ser instada a la jurisdicción judicial familiar.

Una vez que se activa el proceso judicial, para ventilar idéntico asunto que a la par se tramita para conciliación en la vía administrativa, inmediatamente, se mandará archivar el trámite conciliatorio iniciado en la vía administrativa, por mandamiento en la audiencia inicial.

${ }^{40}$ Art. 89 ley 287/1998: "La autoridad administrativa podrá actuar como conciliador en los casos de guarda, alimentos y disputa de las hijas e hijos, procurando intervenir en beneficio del interés superior de las niñas, niños y adolescentes, sin perjuicio de la intervención judicial".

${ }^{41}$ Art. 330 CF: "Sanción en caso de incumplimiento. En caso de incumplimiento de los deberes alimentarios, quien estuviere conociendo del asunto, o a instancia de parte dará cuenta al Ministerio Público, a los fines de establecer la responsabilidad penal que deriva de esta omisión". 
La pena será de dos a tres años de prisión, cuando el autor a sabiendas de su obligación alimentaria se ponga en un estado en el cual le sea imposible cumplir con su deber alimentario o por haber empleado cualquier medio fraudulento para ocultar sus bienes, o haber renunciado o abandonado su trabajo con el fin de evadir su responsabilidad.

También incurrirá en este delito, quien omita el deber alimentario por haber traspasado sus bienes a terceras personas en el plazo comprendido a doce meses anteriores al planteamiento del proceso judicial para el cobro del deber alimentario, durante el proceso judicial de cobro alimentario y hasta seis meses posteriores al dictado de la resolución estimatoria firme de la existencia del crédito alimentario o del deber de satisfacerlo.

Quedará exenta de pena impuesta la persona que pague los alimentos debidos, garantice razonablemente el ulterior cumplimiento de sus obligaciones o garantice convenientemente el cuidado y educación de la persona a su cargo.

El empleador que no realice la retención de los montos del salario del deudor alimentario ordenada por el Juez u oculte información en relación con los salarios u otros aspectos de interés para el establecimiento del monto que debe atender para cumplir el deber alimentario, que haya sido solicitada por la autoridad jurisdiccional, será responsable por desobediencia a la autoridad.

Para los efectos de este artículo, se entenderá como deudores alimentarios también a los hijos en relación a sus padres, cuando estén obligados a prestar alimentos, así como los hermanos con respecto a su hermano incapaz.

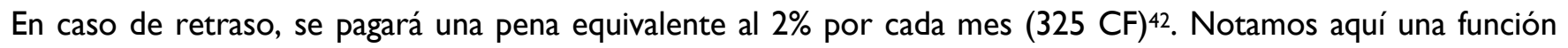
punitiva del dinero cuando se usa para castigar o multar a quien incumple sus obligaciones.

No olvidemos que la falta de pago de los compromisos alimenticios constituye una excepción al principio constitucional que establece que no hay cárcel por deudas (art. 4l Cn) ${ }^{43}$. Este criterio ya era sostenido nuestros magistrados de la Corte Suprema de Justicia aún antes de la aprobación de la actual Constitución: "La disposición que pena como delito no prestar deliberadamente alimentos a un hijo no contradice la regla de que no merece prisión quien incumple una obligación económica” (MONTIEL ARGÜELLO, 1994, p. 32).

\section{I I. Extinción y cesación de la obligación alimenticia}

De conformidad con la Ley 870/2014 se hace una distinción entre la extinción y la cesación de la obligación de pagar los alimentos, según el carácter definitivo de la primera y la posible temporalidad o reversibilidad de la segunda, en el sentido de que variando las circunstancias se podría restaurar la pensión de alimentos. Así, en el art. 33 I CF se indica la muerte de alimentista y del alimentario como las causales de extinción de la obligación de esta índole. En cuanto a cese de las prestaciones alimentarias el art. 332 CF dispone:

\section{Cesación en la obligación de dar alimentos}

ISSN 1993-4505 / No. 19, 2015 / Orozco Gadea

La obligación de dar alimentos cesa:

a) Cuando los hijos e hijas alcancen la mayoría de edad. Los mayores de edad podrán seguir recibiendo alimentos hasta que cumplan los veintiún años de edad, cuando estén realizando estudios, siempre y

\footnotetext{
${ }^{42}$ Art. 325 CF: "Pena por atraso de pago en la pensión alimenticia. El atraso en el pago de las pensiones alimenticias sin causa justificada será penado con el pago de un dos por ciento adicional por cada mes de atraso".

${ }^{43}$ Arto. $41 \mathrm{Cn}$ : "Nadie será detenido por deudas. Este principio no limita los mandatos de autoridad judicial competente por incumplimiento de deberes alimentarios. Es deber de cualquier ciudadano nacional o extranjero pagar lo que adeuda".
} 
cuando no hayan contraído matrimonio ni se hayan declarado en unión de hecho estable y no estén laborando;

b) Cuando los hijos e hijas menores hayan sido emancipados, salvo en casos de enfermedad o discapacidad que le impida obtener por sí mismo los medios de subsistencia;

c) En caso de falta o daños graves del alimentario contra el deudor o deudora de alimentos;

d) Cuando la necesidad de los alimentos resulta de la conducta reprensible del que los solicita o recibe.

Por conducta reprensible podemos suponer casos en que el alimentario se autolesione; o resulte afectado físicamente por participar en carreras ilegales; el jurista CUADRA ZAVALA (2004) se pregunta si ¿Se entenderá por conducta reprensible la falta de aplicación al trabajo? (p. 129).

Consideramos que la respuesta a esta interrogante es afirmativa, cuando el alimentario ostente las condiciones adecuadas para ejercer un oficio o profesión no quiera trabajar.

\section{Conclusiones}

El fundamento de la prestación alimenticia se encuentra en el principio de la solidaridad familiar; sin embargo, nuestra Constitución Política establece en el art. 70 una protección a la familia en una doble vertiente: desde la sociedad y el Estado.

El Código de familia representa el primer esfuerzo codificador en el sentido de aglutinar en un mismo cuerpo de leyes la legislación que antes se encontraba distante y dispersa incluyendo: las pensiones alimenticias.

Las teorías que fundamentan las obligaciones alimenticias se agrupan en dos tendencias: a) el interés por la vida de quien tiene la necesidad y el derecho a los alimentos; b) el interés de superior de la sociedad y el Estado por la vida de sus ciudadanos.

La naturaleza jurídica de esta clase de obligación está configurada por la conjunción de elementos de carácter patrimonial, ético y social que la convierten en una obligación sui generis; que pese a ser una prestación económica, tiene características singulares como ser irrenunciable, imprescriptible, intransferible, inembargable y no compensables.

La correspectividad contenida en el art. 323 inc. i., de la Ley 870 para la procedencia del pago de la pensión de alimentos de los hijos e hijas hacia sus progenitores, representa una verdadera "Ley del talión" que no compartimos porque los alimentos, al igual que el Derecho de familia, están determinados por una amalgama de normas no solo jurídicas, sino éticas, morales e incluso religiosas; en consecuencia, criterios de orden ético, moral e incluso cristiano, prescriben que un hijo se haga cargo de su padre, aún en el caso de que su progenitor lo haya abandonado.

La acción de reforma de una pensión de alimentos, solo es procedente en aquellos casos en que "la situación que la motivó haya cambiado"; y no se debería admitir una acción de esta índole cuando se alegue como motivo únicamente la nueva normativa del Código de familia.

El establecimiento de pensiones alimenticias para los nasciturus, representa un tópico novedoso, sin precedente y muy positivo, que viene brindar protección desde el seno materno; y representa una presunción iuris tantum sobre la paternidad. 
Consideramos que el límite de $2 \mathrm{I}$ años establecido para otorgar alimentos a los hijos que estén realizando estudios, es muy reducido, porque muchos estudiantes con carreras complejas y extensas, probablemente no hayan concluidos sus estudios de pregrado cuando arriben a esa edad.

La pensión compensatoria que se debe enterar a la pareja, en casos de separaciones, representa un elemento positivo que introduce el Código de familia; con ello se pretende mitigar los perjuicios económicos ocasionados por un desequilibrio patrimonial entre los cónyuges o convivientes.

El reconocimiento explícito de las obligaciones alimenticias entre hermanos es una de las novedades muy positivas introducidas por el Ley 870/20 I 4 y viene a llenar el vacío jurídico existente en la antigua normativa: Ley I43/I992.

La facultad discrecional del juez para establecer el monto de las pensiones alimenticias, queda reducida para los casos en que el deudor de alimentos carece de ingresos fijos.

Los porcentajes establecidos en art. $324 \mathrm{CF}$, sin unos respectivos factores de corrección, pueden ocasionar tratamientos injustos en situaciones peculiares de menores de edad que necesiten cuidados o gastos especiales. Consideramos que tales porcentajes pueden ser ponderados por el judicial, según las circunstancias del caso, basado en la distribución equitativa que habla la parte in fine del inciso c) del citado precepto.

El acuerdo notarial hecho en escritura pública sobre la pensión de alimentos y aprobado por la autoridad administrativa o judicial competente, además de introducir un componente innovador, vigoriza el papel de los notarios dentro de los métodos alternos de resolución de los conflictos.

\section{Lista de referencias bibliográficas}

Aguilar García, M. (s.f.). Algunas novedades de Código de familia. Recuperado de http://www.poderjudicial.gob.ni/pjupload/prensa/pdf/novedades familia.pdf

Albaladejo García, M. (2002). Curso de Derecho civil español, t. 4 : Derecho de familia (2ª .ed.), Barcelona: Bosch. Belluscio, A. C. (1985). Manual de Derecho de familia (3a . ed.). Buenos Aires: Depalma.

Bossert G. A., \& ZANNONI, E. A. (2008). Manual de Derecho de familia (6a. ed.) Buenos Aires: Astrea.

BRENES CóRdobA, A. (1974). Tratado sobre las personas. San José: Editorial Costa Rica.

Cañizares Planelles, F.; Córdoba Campos, Ma De R.; García BlazQuez, M. et al. (2004). Diccionario básico jurídico. Granada, España: Comares.

Chávez Asencio, M. F. (2007). La familia en el Derecho (8a. ed.). Pórrua: México

CORTE SUPREMA DE JUSTICIA (2007). Criterios Jurisprudenciales Sala de lo civil 1996-2006. Managua: Centro de documentación e información judicial.

Cuadra Zavala J. (2004). Anotaciones al Código civil de Nicaragua. (t. I), Managua: Hispamer.

del Arco Tórrez, M. A.; Del Arco Blanco M. A. (Coordinadores); Calatayud Pérez, E.; Cañizares

Planelles, F.; Córdoba Campos, Ma de R.; García Blazquez, M. et al. ～(2004). Diccionario básico jurídico. Granada, España: Comares.

Diccionario de la Lengua Española (200I). Real Academia Española (22ª ed.). Madrid: Espasa-Calpe. 
DíEZ PicAZO, L \& Gullón, A. (2002). Sistema de Derecho Civil. (vol. 4): Derecho de familia. Derecho de sucesiones (8. ${ }^{\text {a }}$ ed.), Madrid: Tecnos.

DOMINGo, R. y RODRíGUEZ-ANTOLíN, B. (2000). Reglas jurídicas y aforismos. Con jurisprudencia actualizada y remisiones a la legislación vigente, Navarra: Aranzadi.

HUEMBES \& HUEMBES, J. (197I). Nuevo diccionario de jurisprudencia nicaragüense, Masaya: (s. e.).

Lacruz Berdejo, J. L.; SACNCho Rebudilla, F. de A.; Luna Serrano, A., Delgado Echeverría, F., $\quad$ Rivero HernÁNDeZ, F., y RAMs AlbeSA, J. (2005). Elementos de Derecho civil, (t.4): Derecho de familia (4. a ed.). Barcelona: Bosch, J M.

LeZAMA BALCÁCERES, B. (2000). Referencias de Jurisprudencia civil 1975-1979, 1990-1996. (t. I). Managua: Fondo editorial Banco Central de Nicaragua.

MeZa BarRos, R. (1995). Manual de Derecho de la familia. (t. 2). (3ª ed.). Santiago de Chile: Editorial Jurídica de Chile.

Meza GutiérReZ, A. (1999). Capítulo IV: Derecho de familia. Comentario. En M. A. Acosta Catellón.

Comentarios a la Constitución Política de Nicaragua (pp. 94-99). Managua: Hispamer.

Meza Gutiérrez, A. (2004). Derecho de personas y familia. Managua: Facultad de Ciencias jurídicas de la Universidad Centroamericana.

Montero Duhalt, S. (1984). Derecho de familia. México: Porrua, S. A.

MONTIEl ARgüELLO, A. (1970). Jurisprudencia civil nicaragüense. (t. I). Managua: Imprenta nacional.

MONTIEL ARGÜELlO, A. (1977). Jurisprudencia civil nicaragüense: Suplemento 1970-1974. Managua: Imprenta nacional.

Montiel ARGÜELlO, A. (1994). Jurisprudencia civil nicaragüense 1975-1990. (t. 5). San José: Litografía e imprenta Lil S.A.

Solís Romero, J. A (s.f.). Teoría y práctica del Derecho familiar (2a ed.). Managua: Editorial Jurídica.

\section{Abreviaturas}

Art. Artículo

BJ Boletín Judicial

C Código civil nicaragüense

C Consulta

Cfr. Confrontar

Cons. Considerando

Cn Constitución Política nicaragüense

CT Código del trabajo

Ed. Edición

Inc. Inciso

P. Página

PP. Paginas

S. Sentencia 
SS Siguientes

T. Tomo

TS Tribunal Supremo

Pr. Código de procedimiento civil

Anexos: Tabla comparativa entre la Ley 143, Ley de alimentos y Ley 870, Código de familia

\begin{tabular}{|c|c|c|}
\hline Tema & Ley I43, Ley de alimentos & Ley 870, Código de familia \\
\hline $\begin{array}{l}\text { Alimentos para parientes } \\
\text { distintos de los hijos }\end{array}$ & $\begin{array}{l}\text { Solo se establecía alimentos para } \\
\text { familiares ascendientes y } \\
\text { descendientes (art. 7) }\end{array}$ & $\begin{array}{l}\text { Además de los familiares que } \\
\text { descienden unos de otros; se } \\
\text { determinan derechos } \\
\text { alimenticios para parientes } \\
\text { colaterales hasta el segundo } \\
\text { grado: hermanos y hermanas } \\
\text { (art. } 3 \text { I6. C) }\end{array}$ \\
\hline Pluralidad de deudores & $\begin{array}{l}\text { Se señala la solidaridad entre los } \\
\text { deudores (art. II) }\end{array}$ & $\begin{array}{l}\text { Se indica obligaciones parciarias } \\
\text { en función de la } \\
\text { proporcionalidad de los } \\
\text { ingresos y el capital (parte in } \\
\text { fine del } 316 \text { ) }\end{array}$ \\
\hline $\begin{array}{l}\text { Multa por retraso en el pago } \\
\text { de la prestación alimenticia }\end{array}$ & $\begin{array}{l}\text { Se prescribe una multa del } 5 \% \\
\text { (art. 15) }\end{array}$ & $\begin{array}{l}\text { Se sanciona el retraso con una } \\
\text { penalidad del } 2 \% \text { (art. 325) }\end{array}$ \\
\hline $\begin{array}{l}\text { Juez competente en función } \\
\text { del territorio }\end{array}$ & $\begin{array}{l}\text { No se señala el judicial } \\
\text { competente (art. 19) }\end{array}$ & $\begin{array}{l}\text { Es competente el órgano } \\
\text { judicial del domicilio del menor } \\
\text { (art. 430) }\end{array}$ \\
\hline $\begin{array}{l}\text { Situación de hijos o hijas no } \\
\text { reconocidos }\end{array}$ & $\begin{array}{l}\text { No se ordena realizar la prueba } \\
\text { de ADN (art. 18) }\end{array}$ & $\begin{array}{l}\text { Se ordena hacer la prueba de } \\
\text { ADN (art. 584) }\end{array}$ \\
\hline Medidas cautelares & $\begin{array}{l}\text { Alimentos provisionales (art. 20) } \\
\text { y retención migratoria (art. 22) }\end{array}$ & $\begin{array}{l}\text { La enumeración de las medidas } \\
\text { cautelares es mucho más } \\
\text { amplia (arts. I } 75 \text { y 458) }\end{array}$ \\
\hline $\begin{array}{l}\text { Situación de hijos o hijas } \\
\text { concebidos pero no nacidos }\end{array}$ & $\begin{array}{l}\text { No se establece ningún tipo de } \\
\text { pensión }\end{array}$ & $\begin{array}{l}\text { Gozan del derecho a pensión } \\
\text { de alimentos parte final del art. } \\
3(6 \text { inc. a) y art. } 3 \text { (9) }\end{array}$ \\
\hline $\begin{array}{l}\text { Pensión de alimentos para } \\
\text { hijos mayores de edad }\end{array}$ & $\begin{array}{l}\text { No se determina ningún límite } \\
\text { de edad y se requiere que estén } \\
\text { aprovechando sus estudios (art. } \\
8 \text { parte in fine) }\end{array}$ & $\begin{array}{l}\text { Se señala un límite de } 21 \text { años y } \\
\text { se señala que estén realizando } \\
\text { estudios (arts. } 316 \text { inc. a., y art. } \\
332 \text { inc. a.). }\end{array}$ \\
\hline $\begin{array}{l}\text { Pensión para la pareja en } \\
\text { caso de separación }\end{array}$ & $\begin{array}{l}\text { Solo se prescriben alimentos en } \\
\text { casos de incapacidad para } \\
\text { trabajar por enfermedad o por } \\
\text { motivo similar (art. 9) }\end{array}$ & $\begin{array}{l}\text { Se encuentra reconocida una } \\
\text { pensión compensatoria para el } \\
\text { cónyuge (arts. I59; I63.d; } \\
\text { I64.2; I77; I79.e) }\end{array}$ \\
\hline
\end{tabular}

